\title{
DOROTHEA WALEY SINGER
}

\section{(1882-1964)}

Dorothea Waley Singer, the widow of Professor Charles Singer (1876-1960), the first President of the British Society for the History of Science, died at her home in Cornwall on 24 June 1964 , in her eightysecond year. Her death marks the end of an era, for Charles and Dorothea Singer had been associated with the international societies for the history of medicine and of science since their inception; he was a foundation member of the History of Medicine Section of the Royal Society of Medicine which was founded in 1912, and she was an early member of that section; and they were both foundation members of the British Society for the History of Science.

Dorothea Singer was the second daughter of Nathaniel L. Cohen, L.C.C., a stockbroker, of London and Englefield Green, and of his wife, Julia M. Waley. She was born on I 7 December I882, and after the usual education of girls at that time she spent some years at Queen's College, London, where she took a course which was roughly equivalent to an ordinary B.A. In I9Io she married Charles Singer, and they lived in London until Singer went to Oxford in I9I4. From 1920 they lived in Highgate Village, London, until their removal to Cornwall in I934.

Dorothea Singer was early associated with her husband in papers on the history of medicine. The first was their work on the contagium vivum, which appeared in 1913, and between then and 1927 they published seven papers in collaboration, including important studies of Fracastoro and of the School of Salerno. But Dorothea had meanwhile embarked on her own line of research, dealing mainly with scientific manuscripts dating from before the Renaissance. Her first communication on this subject was delivered to the History of Medicine Section of the Royal Society of Medicine on 15 March I9I6. This was a very thorough study of over r oo manuscript plague tractates dating from about 1348 until I 485. This was the only one of Dorothea Singer's papers or books on pre-Renaissance science or medicine in which the contents were not purely palaeographical. In this paper she discussed very adequately the contents of representative tractates, together with those of the variants. This paper, of over 50 pages, is still not as well known as it ought to be. She had been meanwhile pursuing avidly a cognate line of study-again mainly in the British Museum. This was an attempt to catalogue and codify the manuscripts in the British Isles which bore in any way on science and medicine, and by the end of the First World War she knew of at least 30,000-many of which were of course direct copies or at least variants. On 19 February 1919 she gave to the History Section of the Royal Society of Medicine another paper, in which she discussed the implications of this work and the assistance which would be necessary. 
The full fruition of these studies began to be seen in 1924 , when the Union Académique International, under the editorship of men like Cumont and Lagercrantz, published the first volume of her monumental catalogue of alchemical manuscripts in the British Isles. This first volume is a small work because it deals only with the few Greek manuscripts extant in this country. But the three succeeding volumes, which were published in 1928 , I930, and I93 I respectively, deal with the Latin and vernacular manuscripts, and form a work of great complexity and erudition running to nearly 1,200 pages. It will not easily be supplemented. The result of these long studies of the manuscripts was to make Dorothea Singer a very competent palaeographer, and she lectured frequently on that subject during two long periods in $193^{\circ}$ and $193^{2}$ when she was with her husband at the University of California.

Apart from alchemy and other scientific subjects her interest in plague had been kept alive, and in 1950 she published a definitive catalogue of Latin and vernacular works on plague, dating from before the sixteenth century, in the British Isles. Furthermore, she had extended her calendaring of early manuscripts to cover all scientific subjects. The resulting catalogue was too large to print, but a definitive set of the cards are deposited in the British Museum, and microfilms of them are in some of the other great libraries of the world. In all these palaeographical works she had the devoted assistance of Mrs. Annie Anderson.

In the meantime Dorothea Singer had expounded on other themes with scholarship and enthusiasm. In 1924 she published a carefully annotated selection from the famous English translation by Thomas Johnson of the surgical works of Ambroise Paré, and to her book she prefixed a sympathetic biography of the great French surgeon. In I949-50 she published in three parts an article of over 80 pages on Sir John Pringle and his circle in which she dealt learnedly, and often from a new angle, with many of the great figures of science in Britain in the eighteenth century. This is a very valuable paper which she might easily have expanded to a fairly large book. But from very early in the 193 os she had also been busy with the very difficult writings of Giordano Bruno, and while she was at the University of California in $193^{2}$ she wrote the first draft of a book on that subject. The research still continued, but was interrupted by other activities during the war years; and it was not until r950 that her Giordano Bruno, his Life and Thought appeared. To it was appended her English translation - the first to be done-of Bruno's 'On the Infinite Universe and Worlds', a considerable work which extends to 140 pages. In the biography and study Dorothea Singer showed complete familiarity with the complex thought of Bruno's day, and in her translation she demonstrated equal mastery of the English style used by Florio, the translator of Montaigne.

These manifold activities formed only a part of Dorothea Singer's 
interests. Perhaps her main practical end in life was the caring for the welfare of her distinguished husband. From the time of their residence at Highgate throughout all the years at 'Kilmarth' in Cornwall, Charles and Dorothea provided generous hospitality and stimulating conversation for scholars from many countries. Dorothea Singer had a strong social conscience, and she threw herself with the utmost enthusiasm and determination into any cause in which she was interested. In the years before the Second World War she was one of those who pioneered the placing of refugee girls as student nurses, and very many women are now indebted to her for their start in a new life. She had long suffered from deafness, and over many years she had determined interviews and intensive correspondence with otologists and senior officials of the Ministry of Health regarding the provision of satisfactory hearing aids for all those who were similarly afflicted. These were but two of the many national causes which she championed, and she also devoted herself to local activities such as Women's Institutes and the Red Cross.

Dorothea Singer was a prominent figure in many learned societies. She served for many years on the council of the History Section of the Royal Society of Medicine; and in the British Society for the History of Science she was a vice-president from its foundation in 1947 until 1950. She was also an executive member of the Académie Internationale d'Histoire des Sciences, and a vice-president of the Union International d'Histoire des Sciences, of which body she was for long, and until quite recently, the chairman of its Bibliographical Commission. She was also a Corresponding Member of the Medieval Academy of America. In I 956 she was awarded, jointly with Charles Singer, the Sarton Medal of the History of Science Society of America. Finally, she played an important part, behind the scenes, in promoting the inauguration of a British National Committee for the History of Science.

When Dorothea Singer's Bruno was published in $195^{\circ}$ she was 68 years old, and some diminution of activities might have been expected. But such was not the case. The literary activities still went on. In I955 she published an excellent short biography of Margrieta Beer, one of our British women pioneers in social work. Four years later she published a translation from the German of Professor Klemm's History of Technology. Her last years, after her husband's death in 1960, can only be described as a triumph of mind over matter. Plagued with increasing blindness, and her deafness worsening to such a degree as to be a burden to herself and others, she strove valiantly to demonstrate to herself the truth of her life-long conviction that the only thing that matters is the activity of the human mind.

E. AshWORTh Underwood 